\title{
Structural Characterization of Mullites Synthesized by Thermal Decomposition of Topaz
}

\author{
Robson de Miranda Soares ${ }^{\mathrm{a}}$, Antônio Claret Soares Sabioni ${ }^{\mathrm{a} *}$, Inês Sabioni Resck ${ }^{\mathrm{b}}$, \\ Viviane Aparecida Silva Falcomer, José Alves Dias, , Naira Machado da Silva, \\ Sônia Maria Cabral de Menezes ${ }^{\mathrm{d}}$, Geraldo Magela da Costa ${ }^{\mathrm{e}}$ \\ ${ }^{a}$ Laboratório de Difusão em Materiais, Departamento de Física, \\ Universidade Federal de Ouro Preto, 35400-000 Ouro Preto - MG, Brazil \\ ${ }^{\mathrm{b}}$ Laboratório de Ressonância Magnética Nuclear, Instituto de Química, \\ Universidade de Brasília, CP 4478, 70904-970 Brasília - DF, Brazil \\ 'Pontifícia Universidade Católica do Rio de Janeiro - PUC/RJ, \\ Rua Marquês de São Vicente, 225, 22451-041 Rio de Janeiro - RJ, Brazil \\ ${ }^{\mathrm{d}}$ CENPES/PETROBRÁS, Avenida 1, Quadra 7, Cidade Universitária, \\ Ilha do Fundão, 21949-900 Rio de Janeiro - RJ, Brazil

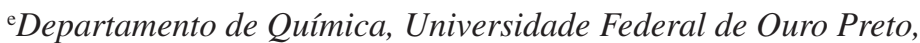 \\ 35400-000 Ouro Preto - MG, Brazil
}

Received: September 18, 2006; Revised: February 1, 2007

\begin{abstract}
The structure of mullite obtained by thermal decomposition of topaz at $1340{ }^{\circ} \mathrm{C}$ and after additional thermal treatment at $1600{ }^{\circ} \mathrm{C}$ was characterized by ${ }^{29} \mathrm{Si}$ and ${ }^{27} \mathrm{Al}$ MAS NMR spectroscopy and $\mathrm{x}$ ray diffraction. No amorphous phase was detected by these techniques. The ${ }^{29} \mathrm{Si}$ MAS NMR spectra of the mullite samples showed four resonance peaks at $-81,-86,-90$ and $-94 \mathrm{ppm}$. The peak at $-81 \mathrm{ppm}$ corresponded to silicon near oxygen vacancies in the mullite structure. The peak at $86 \mathrm{ppm}$ was related to a sillimanite-type site and was the major contribution, ranging from 42 to $50 \%$. The two other peaks, at $-90.0 \mathrm{ppm}$ and $-94 \mathrm{ppm}$, were interpreted as resulting from rearrangements of the sillimanite-type site by the replacement of $\mathrm{AlO}_{4}$ by $\mathrm{SiO}_{4}$ tetrahedra ${ }^{16}$. The ${ }^{27} \mathrm{Al}$ MAS NMR data of the two samples exhibited three different peaks, two of which were attributed to tetrahedral sites at $40-45$ and $63-67 \mathrm{ppm}$, while the third was assigned to an octahedral site at about $-6 \mathrm{ppm}$. The ratio of tetrahedral to octahedral aluminum sites was found to depend on the temperature applied during the preparation of the mullite and was higher at $1600{ }^{\circ} \mathrm{C}$.
\end{abstract}

Keywords: mullite synthesis, topaz, characterization, ${ }^{27}$ Al and ${ }^{29}$ Si MAS NMR, XRD

\section{Introduction}

Mullite is an aluminum silicate widely used in traditional and advanced ceramic materials thanks to its low thermal expansion, low thermal conductivity, and excellent creep resistance. Mullite occurs as solid solution in the silica-alumina binary system ${ }^{1,2}$ and can be described by the following general formula: $\mathrm{Al}_{4+2 \mathrm{x}} \mathrm{Si}_{2-2 \mathrm{x}} \mathrm{O}_{10-\mathrm{x}}$, in which $x$ ranging from 0.17 to 0.59 denotes the number of oxygen vacancies per average unit cell ${ }^{1}$. The end members of this general formula are sillimanite mineral $(x=0)$ and iota-alumina $(x=1)$. In general, the mullite compositions are non-stoichiometric. However, there are stoichiometric compositions such as $3 \mathrm{Al}_{2} \mathrm{O}_{3} \cdot 2 \mathrm{SiO}_{2}(3: 2$ mullite), for $x=0.25$, or $2 \mathrm{Al}_{2} \mathrm{O}_{3} \cdot \mathrm{SiO}_{2}(2: 1$ mullite), for $x=0.4$, in which the $\mathrm{Al}_{2} \mathrm{O}_{3} / \mathrm{SiO}_{2}$ ratio is equal to 1.5 and 2.0, respectively. The mullite structure consists of chains of edge-sharing $\mathrm{AlO}_{6}$ octahedra running parallel to the crystallographic c-axis and crosslinked by double chains of aluminum-oxygen and silicon-oxygen tetrahedra, which also run parallel to the c-axis ${ }^{3}$. This compositional variation in mullite occurs due to the substitution of silicon for aluminum with the simultaneous formation of oxygen vacancies, which can be described by means of a defect formation reaction using Kröger-Vink notation, as follows 4 :

$$
\mathrm{Al}_{2} \mathrm{O}_{3}+2 \mathrm{Si}_{\mathrm{Si}}^{\mathrm{x}}+\mathrm{O}_{\mathrm{o}}^{\mathrm{x}} \leftrightarrow 2 \mathrm{Al}_{\mathrm{Si}}^{\prime}+\mathrm{V}_{\mathrm{o}}^{\circ \circ}+2 \mathrm{SiO}_{2}
$$

Increasing the number of oxygen vacancies per unit cell $(x)$ causes the tetrahedral double chains to become gradually disarranged by removal of bridging oxygen atoms, leading to the formation of new $\mathrm{Al}^{*} \mathrm{O}_{4}$ tetrahedra ${ }^{5}$. Thus, the higher the $x$ value the higher the tetrahedral aluminum to silicon ratio. The crystal structure of mullite has been reviewed elsewhere ${ }^{3-6}$.

Due to the technological importance and widespread industrial use of mullite, which is rare in nature as a mineral, a number of processes to produce synthetic mullites have been designed ${ }^{1}$. One of these methods involves the preparation of mullite from topaz mineral ${ }^{7,8}$, which is a fluorine aluminum silicate whose chemical formula is $\mathrm{Al}_{2} \mathrm{SiO}_{4}\left[\mathrm{~F}(\mathrm{OH})_{1-\mathrm{y}}\right]_{2}{ }^{7}$. This is a very attractive option, since highpurity colorless topaz is abundant in nature and its gemological or commercial value is $l^{8}{ }^{8}$. Moreover, the transformation of topaz to mullite is a clean procedure which does not form chemical residues, in line with the principles Green Chemistry.

This work deals with the structural characterization of mullite synthesized from topaz mineral, using ${ }^{29} \mathrm{Si}$ and ${ }^{27} \mathrm{Al}$ magic angle spinning nuclear magnetic resonance (MAS NMR) spectroscopy and $\mathrm{x}$ ray diffraction (XRD) experiments. An investigation was made into the possible presence of amorphous phase, and the local silicon and aluminum environments in the structure of mullites synthesized 
at $1340{ }^{\circ} \mathrm{C}$ and heat-treated at $1600{ }^{\circ} \mathrm{C}$, which are temperatures frequently used in the fabrication of mullite ceramics by sintering.

\section{Experimental Procedure}

The colorless, transparent and high purity topaz used in this work to produce mullite originated from the state of Minas Gerais, Brazil. The chemical composition of this topaz is shown in Table 1. The topaz was milled in a wet ball mill, using the material itself as the grinding medium (autogenous grinding). After milling, the topaz suspension was oven-dried, followed by heat treatment of the resulting topaz powder in an electric furnace to transform the topaz into mullite. The preparation of mullite by thermal decomposition of topaz occurs through the loss of fluorine, hydrogen and silicon as gases $\mathrm{HF}, \mathrm{H}_{2} \mathrm{O}$ and $\mathrm{SiF}_{4}{ }^{7-9}$. This transformation occurs only at temperatures exceeding $1000{ }^{\circ} \mathrm{C}$ and can be achieved completely at $1300{ }^{\circ} \mathrm{C}$. Two different mullite samples were prepared: M400 at $1340{ }^{\circ} \mathrm{C}$, and M500 at $1600{ }^{\circ} \mathrm{C}$. The M400 mullite was obtained by the thermal decomposition of topaz at $1340{ }^{\circ} \mathrm{C}$ for 3 hours, as indicated in the thermal cycle shown in Figure 1. In the case of the M500 sample, the thermal decomposition was followed by heat treatment at $1600{ }^{\circ} \mathrm{C}$ for 4 hours. The mullite was chemically analyzed by x ray fluorescence (XRF) and microstructurally characterized by scanning electron microscopy (SEM) (Model JSM 5510, JEOL, Japan). Powder $\mathrm{x}$ ray diffraction (XRD) patterns were recorded to analyze the topaz to mullite transformation and the effect of temperature on the mullite structure. The samples were examined by XRD using a diffractometer (Model Shimadzu XRD6000) with FeK $\alpha$ radiation and a graphite monochromator. The scanning rate used was $2 \%$ minutes in the $15-70^{\circ}$ range $(2 \theta)$. Silicon was used as the internal standard. The diffraction data were analyzed using JADE software after subtracting background and stripping the K $\alpha 2$ pattern. ${ }^{29} \mathrm{Si}$ and ${ }^{27} \mathrm{Al}$ MAS NMR experiments were performed on a spectrometer (VARIAN MERCURY plus -7.05 T) at frequencies of 59.6 and $78.2 \mathrm{MHz}$, respectively. The spectrometer was equipped with a $7 \mathrm{~mm}$ CP/MAS probe and the samples were packed in zirconia rotors and spun at the magic angle at 4 and $6 \mathrm{kHz}$ for ${ }^{29} \mathrm{Si}$ and ${ }^{27} \mathrm{Al}$, respectively. ${ }^{29} \mathrm{Si} \mathrm{MAS}$

Table 1. Chemical composition of the colorless topaz.

\begin{tabular}{cccc}
\hline \multicolumn{4}{c}{ Colorless topaz composition (wt. (\%)) } \\
\hline $\mathrm{Al}_{2} \mathrm{O}_{3}$ & $\mathrm{SiO}_{2}$ & $\mathrm{Fe}_{2} \mathrm{O}_{3}$ & $\mathrm{MnO}$ \\
54.9 & 32.5 & 0.07 & $<0.01$ \\
\hline
\end{tabular}

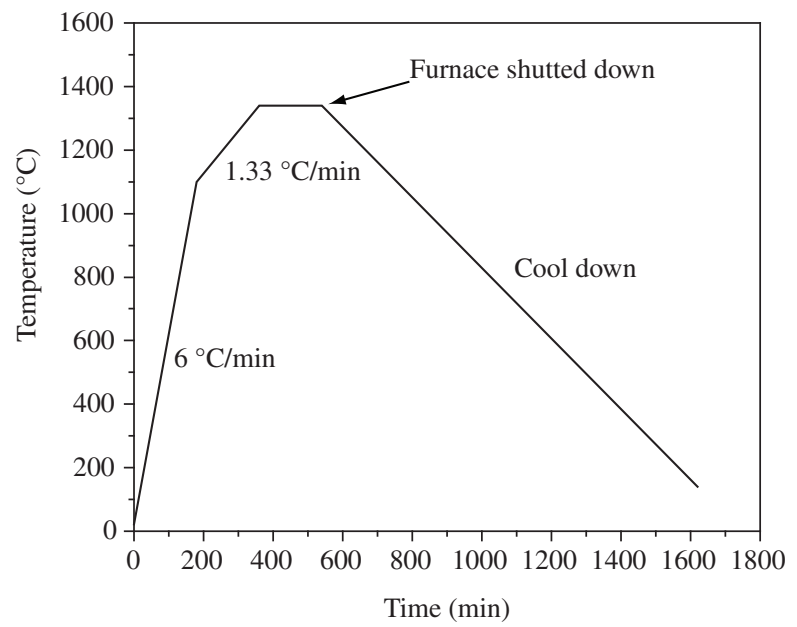

Figure 1. Thermal cycle used for the decomposition of the colorless topaz. spectra were acquired using a spectral width of $100 \mathrm{kHz}$, a single pulse duration of $7.5 \mu \mathrm{s}(\pi / 2)$, a recycle delay of 30 seconds, and an acquisition time of 0.05 seconds, with 500 scans accumulated and referenced to tetramethylsilane (TMS). A line broadening of $10 \mathrm{~Hz}$ and a Gaussian function of 0.003 seconds were applied to process the spectra. The ${ }^{29} \mathrm{Al}$ MAS spectra were recorded using a spectral width of $100 \mathrm{kHz}$, acquisition time of 0.05 seconds, a single pulse duration of $1.0 \mu \mathrm{s}(\pi / 20)$, and a recycle delay of 0.3 seconds, with 15000 scans accumulated and externally referenced to $\mathrm{Al}\left(\mathrm{H}_{2} 0\right)_{6}{ }^{3+}$ $(0.0 \mathrm{ppm})$. The spectra were processed using a line broadening of $25 \mathrm{~Hz}$. The ${ }^{29} \mathrm{Si}$ and ${ }^{27} \mathrm{Al}$ MAS NMR spectra were deconvoluted by the NUTS program. All the ${ }^{29} \mathrm{Si}$ and ${ }^{27} \mathrm{Al}$ spectra were fitted to a sum of partial Gaussian/Lorentzian lines using a gradient algorithm that optimizes the position, width and amplitude of each line.

\section{Results and Discussion}

The $\mathrm{x}$ ray fluorescence analysis of the mullite indicated an $\mathrm{Al}_{2} \mathrm{O}_{3}$ content of $62.0 \pm 0.5(\mathrm{~mol} \%)$ in the M400 and M500 samples, corresponding to a nonstoichiometric mullite composition with an $\mathrm{Al}_{2} \mathrm{O}_{3} / \mathrm{SiO}_{2}$ ratio of 1.63 . The number of oxygen vacancies per average unit cell $(x)$ was calculated by means of the expression ${ }^{10}$ :

$$
x=10-6 \cdot \frac{m+200}{m+100}
$$

where $\mathrm{m}$ is the alumina content in the mullite (mol \%). The $x$-value for the M400 and M500 samples was found to be 0.30 . It is worth noting that the $\mathrm{Al} / \mathrm{Si}$ ratio increased from 2 in topaz to 3.26 in the M400 and M500 samples. This increase was due to the loss of silicon in the form of $\mathrm{SiF}_{4}$ gas during the thermal decomposition of topaz. Figure 2 shows a SEM micrograph of mullite obtained by thermal decomposition of topaz at $1340{ }^{\circ} \mathrm{C}$ for 3 hours. This mullite showed a needle-like microstructure (mullite whiskers), which is characteristic of mullite obtained by the decomposition of topaz ${ }^{8}$.

The experimental conditions used here resulted in very pure mullite without amorphous phase, as depicted in Figures $3 \mathrm{a}$ and $3 \mathrm{c}$. No topaz phase was visible in the XRD pattern of the prepared mullites (M400 and M500). Table 2 shows the lattice parameters and the unit cell volumes of M400 and M500 samples obtained by x ray diffraction. As can be seen in these figures, increased temperatures did not significantly modify the mullite crystalline structure. $\mathrm{X}$ ray diffraction data has proved to be a useful tool to estimate the alumina content in mullite. Several authors, working with mullite solid solutions obtained

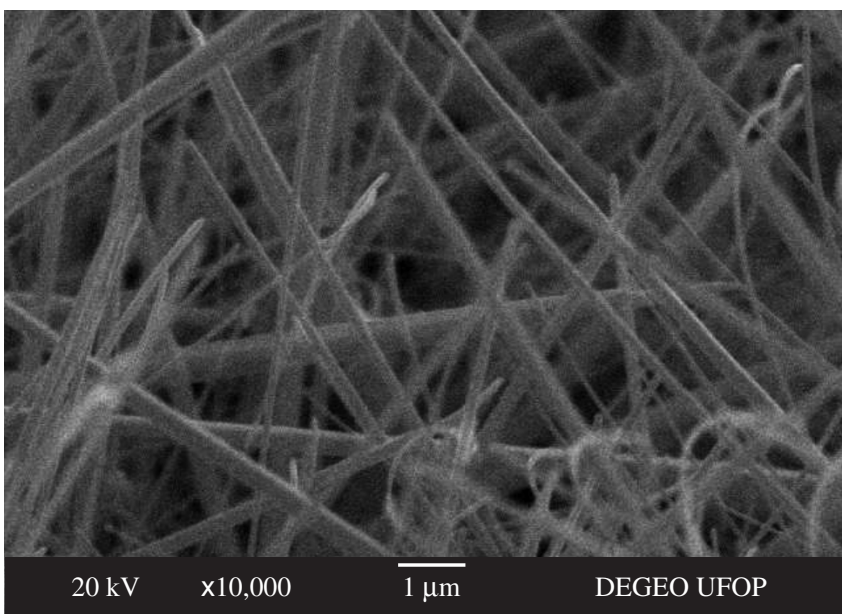

Figure 2. SEM micrographs of the mullite derived from the decomposition of colorless topaz heated at $1340{ }^{\circ} \mathrm{C}$ during 3 hours. The needle-type microstructure is observed as a fiber network $(\mathrm{x} 10000)$. 
by different processes, have found a linear dependence between alumina content $(\mathrm{m})$ and the a-lattice parameter. Using, for example, the relationship established by Fischer et al. ${ }^{10}$ as follows:

$$
\mathrm{m}(\% \mathrm{~mol})=144.5 \mathrm{a}(\AA)-1029.5
$$

one finds an alumina content of $63.35 \pm 1.50$ (\% mol) in mullite obtained from topaz, which is reasonably consistent with the value of $62.0 \mathrm{~mol} \%$ found in our $\mathrm{x}$ ray fluorescence analysis.

${ }^{29} \mathrm{Si}$ and ${ }^{27} \mathrm{Al}$ MAS NMR experiments were used for the first time to characterize the structure of mullite obtained from topaz, and led to the determination of the local environment of silicon and aluminum atoms in the structure of the M400 and M500 samples.

According to the literature, the structure of mullite from different sources and with various compositions has four NMR silicon tetrahedral sites typically at $-81,-86,-90$ and $-94 \mathrm{ppm}^{11-20}$. These local environments of $\mathrm{Si}$ atoms were also observed in the structure of mullite obtained from topaz, and were similar in the M400 and M500 samples. Figure 4 shows the ${ }^{29} \mathrm{Si}$ MAS NMR deconvoluted spectra of the M400 and M500 samples. The high frequency peaks at -81.0 and $-80.7 \mathrm{ppm}$, determined with 22 and 18\%, respectively, for the M400 and M500 samples, are assigned to the local arrangement of the ( $\mathrm{Si}$, $\left.\mathrm{Al}, \mathrm{Al}^{*}\right)$ cluster $^{13}$ and correspond to silicon near oxygen vacancies in the mullite structure ${ }^{17}$. Site 2 at $-86.3 \mathrm{ppm}$ in both samples is related to a sillimanite-type site ${ }^{16-21}$ and corresponded to the major contribution, which ranged from 42 to $50 \%$. The two other peaks at $-90.0 \mathrm{ppm}$ $(25-29 \%)$ and $-93.9 \mathrm{ppm}(7 \%)$ were interpreted as resulting from rearrangements of the sillimanite-type site by the replacement of
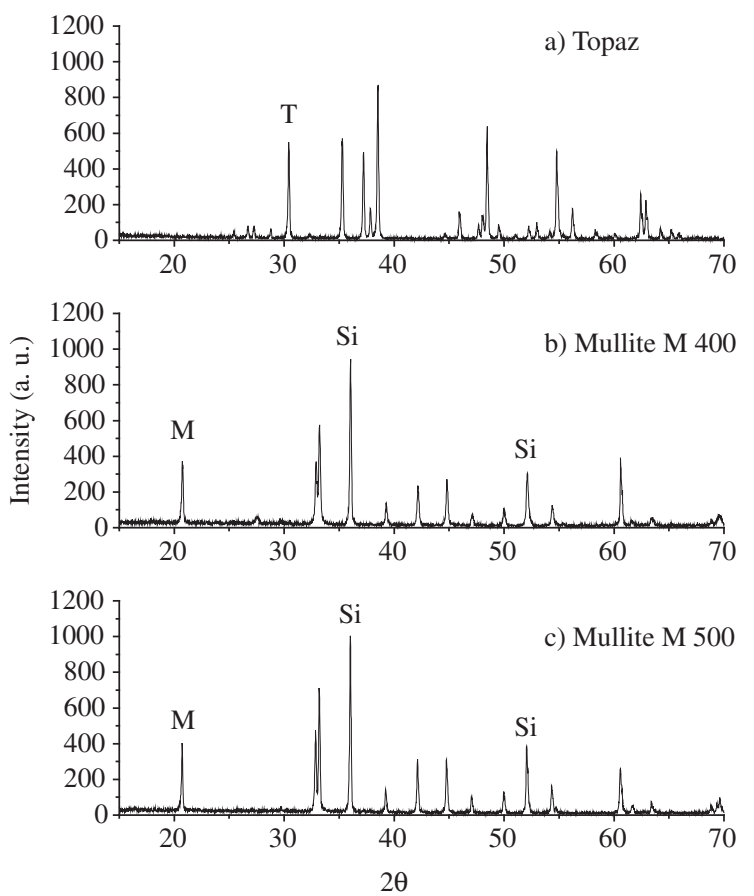

Figure 3. Powder XRD patterns for a) colorless topaz, b) M400 sample, and c) M500 sample.

Table 2. Unit cell parameters and unit cell volume of mullite.

\begin{tabular}{ccccc}
\hline Samples & \multicolumn{3}{c}{ Cell parameters $(\AA)$} & Volume \\
\cline { 2 - 4 } & $\mathrm{a}$ & $\mathrm{b}$ & $\mathrm{c}$ & $\left(\AA^{3}\right)$ \\
\hline M 400 & $7.563 \pm 0.008$ & $7.685 \pm 0.002$ & $2.885 \pm 0.002$ & 167.70 \\
M 500 & $7.568 \pm 0.002$ & $7.682 \pm 0.005$ & $2.885 \pm 0.002$ & 167.71 \\
\hline
\end{tabular}

one or two $\mathrm{AlO}_{4}$ by $\mathrm{SiO}_{4}$ tetrahedra ${ }^{16}$. A possible amorphous phase in the mullite would generate a resonance peak at around $-110 \mathrm{ppm}^{11-20}$, which was not observed at the ${ }^{29} \mathrm{Si}$ spectra shown in Figure 4, thus corroborating our $\mathrm{x}$ ray diffraction measurements.

Figure 5 illustrates the deconvoluted ${ }^{27} \mathrm{Al}$ MAS NMR spectra of the M400 and M500 samples, showing three distinct signals for aluminum sites. These signals were attributed to an octahedral site and two tetrahedral sites, and have also been detected in other mul-
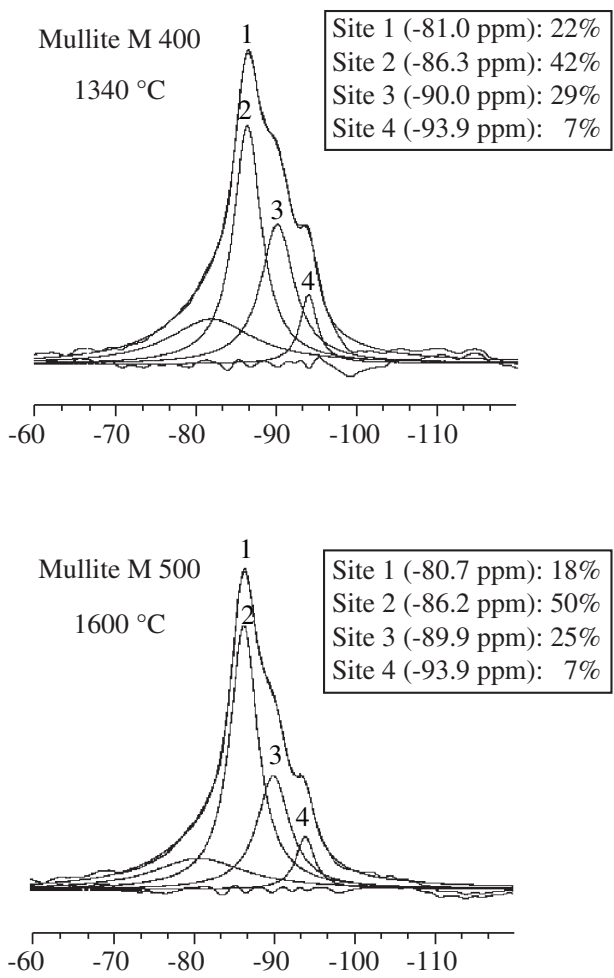

Figure 4. Experimental and deconvoluted ${ }^{29} \mathrm{Si}$ MAS NMR spectra of the M400 and M500 samples.

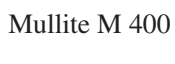

Site $1(67.0 \mathrm{ppm}): 16 \%$ Site 2 (45.0 ppm): $33 \%$ $1340{ }^{\circ} \mathrm{C}$ Site 3 (-5.7 ppm): $51 \%$

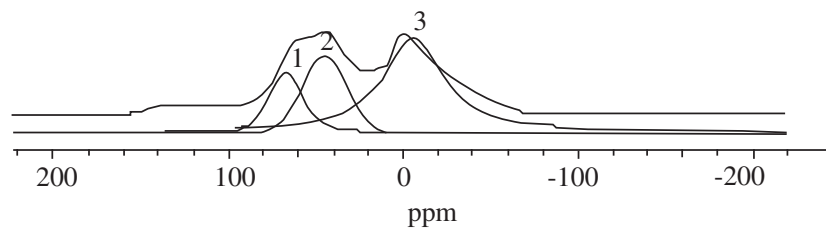

Mullite M 500

$1600{ }^{\circ} \mathrm{C}$

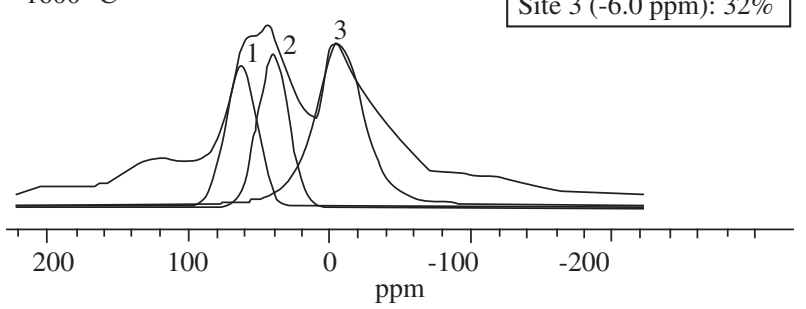

Figure 5. Experimental and deconvoluted ${ }^{27} \mathrm{Al}$ MAS NMR spectra of the M400 and M500 samples. 
lites obtained from different sources ${ }^{18-20,22}$. In the samples used in this work, an octahedral site at $-5.7 \mathrm{ppm}$ and two tetrahedral sites at 45.0 and $67.0 \mathrm{ppm}$ were observed in the structure of the M400 sample, while the same three sites were assigned to $-6.0,40.0$ and $63.0 \mathrm{ppm}$ in the M500 sample. The intensity of the tetrahedral occupancy at $63.0 \mathrm{ppm}$ in the M500 sample increased $(16 \rightarrow 33 \%)$ after the sample was heat-treated at $1600{ }^{\circ} \mathrm{C}$, while the octahedral one at $-6.0 \mathrm{ppm}$ decreased $(51 \rightarrow 32 \%)$, revealing three signals with approximately the same intensities $(33: 35: 32)$.

\section{Conclusions}

${ }^{27} \mathrm{Al}$ and ${ }^{29} \mathrm{Si}$ MAS NMR and $\mathrm{x}$ ray diffraction was used to characterize the mullite structures obtained by heat-treating topaz at $1340{ }^{\circ} \mathrm{C}$ and $1600{ }^{\circ} \mathrm{C}$. Neither of these techniques revealed any amorphous phase in the various mullite samples. The four resonance peaks in the ${ }^{29} \mathrm{Si}$ spectra at $-81,-86,-90$ and $-94 \mathrm{ppm}$, obtained by simulation with Gaussian/Lorentzian functions, were nearly the same at $1340^{\circ}$ and $1600{ }^{\circ} \mathrm{C}$, with the main contribution $(42-50 \%)$ represented by the sillimanite-type site at $-86 \mathrm{ppm}$. The ${ }^{27} \mathrm{Al}$ MAS NMR data revealed three different peaks in the mullite samples, two of which were attributed to tetrahedral sites at 40-45 and 63-67 ppm while the third was assigned to an octahedral site at about $-6 \mathrm{ppm}$. The tetrahedral to octahedral aluminum site ratio, which was found to depend on the heat-treatment temperature, was higher at $1600{ }^{\circ} \mathrm{C}$.

\section{Acknowledgments}

The authors are grateful to FAPEMIG, CNPq, IQ|UnB and FINEP (grant CT-INFRA 970/2001) for financial support, and also to CENPES - PETROBRAS.

\section{References}

1. Schneider H, Okada K, Pask JA. Crystal chemistry of mullite, pp. 4-30 in: Mullite and Mullite Ceramics. England: John Wiley \& Sons Ldt; 1994.

2. Pask JA. Importance of starting materials on reactions and phase equilibria in the $\mathrm{Al}_{2} \mathrm{O}_{3}-\mathrm{SiO}_{2}$ system. Journal European Ceramic Society. 1996; 16(14):101-108.

3. Johnson BR, Kriven WM, Schneider J. Crystal structure development during devitrification of quenched mullite. Journal European Ceramic Society. 2001; 21(14):2541-62.

4. Fielitz P. et al. Self-diffusion of Oxygen in Mullite. Journal European Ceramic Society. 2001; 21(14):2577-82.

5. Schneider H, Eberhard E. Thermal expansion of mullite. Journal American Ceramic Society. 1990; 73(67):2073-76.
6. Cameron WE. Mullite-substituted alumina. American Mineralogist. 1977; 62(7-8):747-55.

7. Sabioni ACS. et al. Imperial topaz from Ouro Preto, Brazil: chemical character and thermal behaviour. Journal Gemmology. 2003; 28(5):283.

8. Monteiro RR, Sabioni ACS, Costa GM. Preparação de mulita a partir do mineral topázio. Cerâmica. 2004; 50(316):318-23.

9. Day RA, Vance ER, Cassidy DJ. The topaz to mullite transformation on heating, J. Materials Research. 1995; 10(11):2963-69.

10. Fischer RX, Schneider H, Voll D. Formation of Aluminium Rich 9:1 Mullite and its Transformation to Low Alumina Mullite upon Heating. Journal European Ceramic Society. 1996; 16(2):109-113.

11. Merwin LH. et al. ${ }^{29} \mathrm{Si}$ and ${ }^{27} \mathrm{Al}$ MAS NMR Spectroscopy of Mullite. Phys. Chem. Minerals. 1991; 18(7):47-52.

12. Schneider H, Merwin LH, Sebald A. Mullite formation from noncrystalline precursors. Journal Material. Science. 1992; 27(3):805-12.

13. Ban T, Okada K. Analysis of local cation arrangement in mullite using ${ }^{29} \mathrm{Si}$ magic-angle spinning nuclear magnetic resonance spectra. Journal American Ceramic Society. 1993; 76(10):2491-96.

14. Selvaraj U, Komarneni S, Roy R. Structure differences in mullite xerogels from different precursors characterized by ${ }^{27} \mathrm{Al}$ and ${ }^{29} \mathrm{Si}$ MAS NMR. $J$. Solid State Chem.. 1993; 106(1):73-82.

15. Jaymes L. et al. New synthesis of mullite. Structural evolution study by ${ }^{17} \mathrm{O},{ }^{27} \mathrm{Al}$ and ${ }^{29} \mathrm{Si}$ MAS NMR Spectroscopy. J. P. J. Sol-Gel Sci. Technol.. 1994; 2(1-3):367-70.

16. Jaymes I. et al. Evolution of the Si environment in mullite solid solutions by ${ }^{29} \mathrm{Si}$ MAS-NMR spectroscopy. Journal of Non-Crystalline Solids. 1996; 204(2):125-134.

17. Gomes S, François M. Characterization of mullite in silicoaluminous fly ash by XRD, TEM, and ${ }^{29} \mathrm{Si}$ MAS NMR. Cem. Concr. Res.. 2000; 30:175-81.

18. Zhao H, Hiragushi K, Mizota Y. ${ }^{27} \mathrm{Al}$ and ${ }^{29} \mathrm{Si}$ MAS-NMR studies of structural changes in hybrid aluminosilicate gels. Journal European Ceramic Society. 2002; 22(9-10):1483-91.

19. Zhao H, Hiragushi K, Mizota, Y. Phase segregation on non-stoichiometric aluminosilicate gels characterized by ${ }^{27} \mathrm{Al}$ and ${ }^{29} \mathrm{Si}$ MAS-NMR. Journal of Non-Crystalline Solids. 2002; 311:99-206.

20. He H. et al. ${ }^{29} \mathrm{Si}$ and ${ }^{27} \mathrm{Al}$ MAS NMR spectra of mullite from different kaolinites. Spectrochim. Acta Part A. 2004; 60(5):1061-1064.

21. Schmucker M. et al. $\mathrm{AlO}_{4} / \mathrm{SiO}_{4}$ distribution in tetrahedral double chains of mullite. Journal American Ceramic Society. 2005; 88(10):2935-2937.

22. Bodart PR. et al. Aluminium environments in mullite and an amorphous sol-gel precursor examined by ${ }^{27} \mathrm{Al}$ triple-quantum MAS NMR. J. Phys. Chem. Solids. 1999; 60(2):223-228. 